\title{
Factors influencing pine needle consumption by grazing cattle during winter
}

\author{
JAMES A. PFISTER AND DON C. ADAMS
}

\begin{abstract}
Pfister is range scientist, USDA-ARS Poisonous Plant Research Lab., Logan, Ut. 84321; Adams is associate professor, Univ. of Nebraska-Lincoln, at North Platte 69101.
\end{abstract}

\begin{abstract}
Ponderosa pine (Pinus ponderosa Lawson) needles cause abortions in pregnant cows. We examined pine needle consumption by cattle in 2 trials in eastern Montana. Trial 1 compared pregnant and open cows $(n=4)$ from January to March 1989; trial 2 compared pregnant cattle $(n=4)$ that received either $9 \mathrm{~kg}$ alfalfa hay head $^{-1}$ day $^{-1}$ or $1.4 \mathrm{~kg}$ alfalifa pellets head ${ }^{-1}$ day $^{-1}$ from December 1989 to February 1990. Diets were estimated using both bite counts and fecal analysis. During trial 1, bite counts revealed pregnant and open cows consumed 45 and $42 \%$ of their grazing diets as pine needles $(P>0.1)$. Fecal analysis showed that pregnant cows consumed more pine needles than did open cows (36\% vs. $27 \%$, respectively) $(P<0.05)$. During trial 2 , cattle consumed $<1 \%$ of their diets as pine needles. In trial 1 cattle consumed less pine litter and consumed more needles from trees as snow depth increased. Consumption of needles from trees increased as ambient temperature declined; no needles were consumed from trees when the minimum daily temperature exceeded $-5^{\circ}$ C. During both trials, grazing times decreased as temperatures declined, and increased as snow depth and wind speed decreased. We conclude that weather is a major factor influencing needle consumption; other interrelated factors may be forage availability, snow cover, and grazing time. Pine needle consumption, and the risk of abortion, in pregnant cattle appears to be greatly diminished during mild winter weather.
\end{abstract}

Key Words: Pinus ponderosa, cattle diets, poisonous plants, grazing behavior, abortion

Ponderosa pine (Pinus ponderosa Lawson) trees occupy about 17 million ha of rangeland in western North America (Gartner et al. 1988). Abortion or premature birth can result when pregnant cattle ingest needles (James et al. 1989). The risk of abortion increases as pregnancy advances and is highest during the last trimester of gestation (Short et al. 1989). In addition to abortion, losses attributed to ingestion of pine needles include dead or weak calves at birth, retained placentas and endometritis in parturient cows, poor reproductive performance following abortion, and the cost of keeping cattle out of pine-tree infested areas and providing alternative forages (Lacey et al. 1988).

Several pen-studies have conclusively shown that pine needles cause abortion in cattle and that penned cattle will eat the needles (MacDonald 1952, James et al. 1977, James et al. 1989). Penned cows given hay and needles free choice consumed up to $20 \%$ of their diet as fresh pine needles (MacDonald 1952).

There is little information about the consumption of pine needles by grazing animals, particularly during winter when abortions

Partial support provided by the Utah Agr. Exp. Sta., Logan, Utah. Journal article 4305. The authors wish to thank Tim Donnelly for providing facilities and animals for the study; Bob Short for palpating cows; and Alan Charles, Nori Hildenstab, Lynn Kitchen, Wayne Milmine, Tracy Weber, Kermit Price, and Kevin Petersen for assistance with various aspects of the study. We also thank the support staff at the USDA-ARS Range and Livestock Exp. Sta., Miles City, Mont. for willing assistance. Manuscript accepted 27 Jan. 1993. typically occur. In western Australia grazing sheep consumed substantial amounts of Pinus radiata needles (Anderson et al. 1985). Diets of grazing cattle consisted of 4 to $9 \%$ pine needles from June to September in the Black Hills of South Dakota (Uresk and Paintner 1985). On ponderosa-pine ranges in Colorado, deer consumed large amounts of needles from May to November, but cattle consumed none (Currie et al. 1977).

The objectives of these studies were to (1) determine the amount of pine needles consumed by pregnant and open cows, and to relate consumption patterns to environmental conditions; and (2) to determine if supplementation affects pine needle consumption. We initially compared pregnant and open cows to determine if it was necessary to use pregnant cows (with subsequent risk of abortion) in future studies. We hypothesized that cattle would eat more needles during severe winter weather, and that supplementation would attenuate needle consumption.

\section{Materials and Methods}

Trial 1

Trial 1 was conducted from 25 Jan. to 15 Mar. 1989 in a 16-ha pasture located $24 \mathrm{~km}$ east of Miles City, Mont. Ponderosa pine trees were abundant on the pasture; topography varied from hilly to very steep breaks. Other readily available browse included yucca (Yucca glauca Nutt.), skunkbrush (Rhus trilobata (Nutt.) Gray), and sagebrush (Artemisia tridentata Nutt.). There was very little carryover dormant grasses or forbs due to the limited production during the previous summer's severe drought.

Density of pine trees was estimated by counting the number of pine trees inside 10 randomly located $20 \times 20-\mathrm{m}$ plots. Trees were arbitrarily divided into 3 height classes: $<1 \mathrm{~m}$ (small), 1 to $2 \mathrm{~m}$ (medium), and $>2 \mathrm{~m}$ (large). On 19 Jan. 1989, twenty $0.25-\mathrm{m}^{2}$ quadrats were randomly placed on ground blown free of snow to estimate the amount of available pine needle litter. Needles within the quadrat were collected, dried, and weighed. This placement was necessary because much of the pasture was snow covered. The amount of pine litter exposed for grazing varied throughout the study because of shifting wind patterns. Amount of needles available was estimated by harvesting all needles from 20 randomly selected pine trees $<2-\mathrm{m}$ tall. Needles were subsequently dried at $50^{\circ} \mathrm{C}$ for 48 hours and weighed. Height was recorded of these 20 trees, plus an additional 10 trees in the same height class. A regression equation was developed to relate the height above the snow of the first 20 trees to amount of needles on the trees: $Y=-47.5+1.71 X\left(r^{2}=.90, S_{y . x}=7.1, n=20\right)$, where $Y$ is grams of pine needles per tree, and $X$ is visible tree height in centimeters. Since there was about $200 \mathrm{~mm}$ of snow on the level, and more in drifts, virtually all trees used to develop this equation were $>280-\mathrm{mm}$ tall; few trees smaller than this were visible. An additional 10 pine trees $>2-\mathrm{m}$ tall were also randomly selected, and all needles up to a browsing height of $2 \mathrm{~m}$ were stripped, dried, and weighed. We 
assumed that needles above $2 \mathrm{~m}$ were unavailable for browsing cows.

Four pregnant and 4 open Hereford $\times$ Angus mature (about 7-8 years old) cows weighing about $500 \mathrm{~kg}$ were used in the study. These cows were native to the ranch where the study was conducted and were grazing a pasture adjacent to the study area at the start of the study. The cows were offered about $7 \mathrm{~kg}$ of alfalfa-grass hay/head at 0830 hours; actual consumption after trampling is unknown. The cows generally finished consuming the hay near 1100 hours, and would begin grazing from 1200 to 1500 hours. Cows never began grazing before 1200 hours. Pine tree cover was available about $75 \mathrm{~m}$ from the feeding ground.

Two pregnant and 2 open cows were fitted with 8-day vibracorders to record grazing time. Total minutes grazed during 2 time periods (1200 to 1759 hours, 1800 to 0800 hours) were calculated from vibracorder charts. Hourly weather information was taken about $20 \mathrm{~km}$ from the study site at an automated weather station operated by the USDA-ARS; these data were summarized to provide daily average, maxima, and minima for temperature and wind speed.

Diets were quantified using bite counts as the principal technique. Beginning on 31 Jan., each cow was focally sampled (Altmann 1974) for several 5-min periods each day, and bites (i.e., a head pull associated with severing herbage) recorded for 3 categories of pine needles (tree $>1-\mathrm{m}$ tall; tree $<1-\mathrm{m}$ tall; and litter), yucca, other browse, and other plants (grass, forbs). The observer made continuous, sequential observations of the cows during diurnal grazing periods. Snow depth was measured at the cow's position when the 5-min bite count was finished; we also calculated the average daily snow depth associated with each cow.

To estimate the average daily needle consumption, bite rate (bites $\mathrm{min}^{-1}$ ) and size of pine needle bites ( $\mathrm{g} / \mathrm{bite}$ ) were estimated. Bite weights were estimated by weighing amount of needles in 20 hand-plucked "average" bites. Needle weights (oven-dry) ranged from 1 to $3 \mathrm{~g} /$ bite; we used $2 \mathrm{~g} /$ bite in all calculations. Daily bite rate was calculated as bites $\mathrm{min}^{-1}$ for each animal using total bites and total observation time. Grazing time during daylight (1200 to 1800 hours) was taken from vibracorders. Pine needle bite rate $X$ grazing time $X$ bite size was used to estimate needle consumption day $^{-1}$.

Fecal samples were examined as a secondary source of diet information because we were concerned that cattle may consume pine needles at night. Fecal samples were collected from each cow twice weekly beginning on $25 \mathrm{Jan}$. 1989. A small amount of feces was collected from freshly deposited dung piles, mixed 1:1 with salt, and refrigerated. The microhistological technique (Sparks and Malechek 1968) was used to quantify diets based on fecal analysis. Four microscope slides were made from each sample, and 25 fields (100x magnification) were read on each slide. Generally there were at least 4 identifiable particles/field. The observer was trained on mixtures of plants from the pasture; in blind tests observer accuracy was $\pm 2 \%$ for pine needles. Because passage of pine needles through the rumen is variable (Pfister et al. 1992), we did not believe that fecal pine needle levels could be related to specific dates, climatic variables (e.g., MDT), or snow depth. In calculating grazing diets using fecal values, we eliminated alfalfa hay and assumed that $15 \%$ of the grass in fecal material was from the mixed alfalfa/grass hay fed to cows, since inspection of the hay indicated about $15 \%$ grass.

\section{Trial 2}

Trial 2 began on 27 December 1989 and was completed on 15 February 1990 . Study area was a 50 -ha pasture located adjacent to the Trial 1 pasture; topography was hilly, with several large open areas contained within the pasture. Eight pregnant Hereford $X$
Angus cows $(520 \pm 65 \mathrm{~kg})$ were randomly divided into 2 treatment groups ( $n=4)$ : one group was individually fed $9 \mathrm{~kg} \mathrm{head}^{-1}$ of alfalfa hay, and the other group was individually fed $1.4 \mathrm{~kg}$ of alfalfa cubes head $^{-1}$ day $^{-1}$. The amount of hay fed was slightly above maintenance dry matter intake requirements for pregnant cows (NRC 1984). Cubes were fed at a rate of $1 \mathrm{~kg}$ per $150 \mathrm{~kg}$ of body weight, which was estimated as providing about $50 \%$ of NRC (1984) protein requirements. Initially, cows were supplemented daily, but because this was found to be disruptive of grazing behavior, we began feeding supplement every other day on 8 Jan. Grass was abundant in the pasture, and the cows frequently did not consume the supplemental feed.

Herbage standing crop was determined by clipping thirty $0.5-\mathrm{m}^{2}$ randomly placed plots. Pine trees occurred as dense, scattered stands of juvenile and adult trees. Within stand densities were measured using fifteen $10 \times 20$-m plots for the size classes described previously. Pine needle litter biomass was determined in these pine tree areas using thirty $0.25-\mathrm{m}^{2}$ plots. A regression approach similar to the 1989 trial was used to determine needle biomass up to $2 \mathrm{~m}$ in height with 10 randomly selected trees $\geq 2 \mathrm{~m}$ in height measured and stripped of needles $\left(Y=-30.7+1.78 X, r^{2}=0.80, S_{y . x}=11.0, n=30\right.$, where $\mathrm{Y}$ is the predicted needle weight $(\mathrm{g})$ per tree, and $\mathrm{X}$ is height in $\mathrm{cm}$ ). An additional 30 trees were measured for height, and the equation used to determine needle biomass on trees $\leq 2 \mathrm{~m}$ tall.

Grazing time was again quantified using vibracorders on 3 animals per treatment. However, data during all hours in this trial were analyzed by time period: 1800 to 0559,0600 to 1159 and 1200 to 1759 hours.

Bite counts were used as in the previous trial to determine consumption of pine needles. We also used fecal samples taken 2 to 3 times weekly as an alternative method to determine diets. Methods for the fecal analysis were identical to those previously described. Weather variables were measured as in the previous study.

\section{Statistical Procedures}

Grazing time data was analyzed using analysis of variance procedures (SAS 1987). The model followed that of Adams et al. (1986), and included as main effects pregnant vs. open cows and snow depth $(<25,25-150,>150 \mathrm{~mm})$, with minimum daily temperature (MDT) and average wind speed (AWS) as covariates. The same model was used to test for differences in diets as determined by bite counts. A $t$-test was used to compare the composition of fecal material in both trials.

\section{Results}

\section{Trial 1}

Fecal analysis indicated that alfalfa hay comprised about $55-60 \%$ of cattle diets, and there was no difference $(P>0.1)$ in alfalfa hay consumption due to pregnancy. Cattle grazing bites consisted of $>40 \%$ pine needle (Table 1). Physiological status had no influence $(P>0.05)$ on total pine needle bites or on bites of needles from trees or litter. Pregnant cattle had a greater percentage of pine needles in fecal material than did open cattle (Table 1). Cattle consumed about 2,500 to $3,000 \mathrm{~g}$ of pine needles during a typical daytime grazing period (Table 1). Pregnant cows consumed $261 \mathrm{~g} /$ day of pine needles from saplings ( $<1-\mathrm{m}$ tall) compared to only $12 \mathrm{~g}$ for open cows $(P<0.05)$.

Bites of yucca and amounts of yucca in feces were influenced by pregnancy (Table 1), with open cows consuming $>200 \%$ more yucca. Bites of browse (other than pine needles) did not differ because of physiological status, but percentage of browse in feces was greater for pregnant than for open cows. Grass consumption was similar in both pregnant and open cows. 
Table 1. Grazing diets ${ }^{2}(\%$ of bites, \% of fecal material, and $g /$ day) of pregnant and open cows in Trial 1 during January to March 1989, in eastern Montana.

\begin{tabular}{|c|c|c|c|c|c|c|c|c|c|}
\hline & \multicolumn{9}{|c|}{ Cow physiological status } \\
\hline & Preg $^{b}$ & Open & $\mathrm{MSE}^{\mathrm{c}}$ & Preg $^{\mathrm{b}}$ & Open & $\mathrm{SE}^{\mathrm{c}}$ & Preg $^{b}$ & Open & $\mathrm{MSE}^{\mathrm{c}}$ \\
\hline \multirow{3}{*}{$\begin{array}{l}\text { Pine needle litter } \\
\text { Pine needles- from } \\
\text { trees }<1 \mathrm{~m}\end{array}$} & & 0 of bit & & $\ldots$ & 6 in fec & & & (g/day) & \\
\hline & 32 & 37 & 39 & - & - & - & 2864 & 2262 & 4053 \\
\hline & 8 & 1 & 14 & - & - & - & 261 & $12^{+}$ & 618 \\
\hline trees $>1 \mathrm{~m}$ & 5 & 4 & 12 & - & - & - & 53 & 167 & 316 \\
\hline Total pine needles & 45 & 42 & 41 & $36^{*}$ & 27 & 2.5 & 3175 & 2441 & 4169 \\
\hline Browse & 35 & 20 & 23 & $45^{*}$ & 37 & 2.3 & 一 &.- & - \\
\hline Yucca & 7 & 26 & 22 & $7^{*}$ & 20 & 1.5 & - & - & - \\
\hline Grasses & 14 & 12 & 10 & 13 & 16 & 3.3 & - & - & - \\
\hline $\begin{array}{l}\text { Pine needle bite rate } \\
\text { (bites/min) }\end{array}$ & 16 & 14 & & & & & & & \\
\hline
\end{tabular}

${ }_{b}^{a}$ Does not include hay intake-see methods.

bPreg=pregnant, open=not pregnant.

${ }^{\mathrm{C}} \mathrm{MSE}=$ =root MSE, $\mathrm{n}=195$ for all dietary items for bite counts; $S E=$ standard error, $\mathrm{n}=60$ for fecal analysis; $\mathrm{n}=87$ for $\mathrm{g} /$ day of pine needles.

$+P<E=$ root MSE,

As snow depth increased, cattle consumed less pine litter, and more needles from trees and other browse (Table 2). Minimum daily temperature affected the amount of needles consumed from trees $(P=0.08)$. At minimum daily temperatures greater than $-5^{\circ} \mathrm{C}$, cattle consumed no needles from trees; at $-25^{\circ} \mathrm{C}$ cattle consumed over $300 \mathrm{~g} /$ day of needles from trees.

Table 2. Effect of snow depth on cattle grazing bites (\% of bites) during winter, 1989, in eastern Montana.

\begin{tabular}{|c|c|c|c|c|c|}
\hline \multirow[b]{2}{*}{ Item } & \multicolumn{3}{|c|}{ Snow depth (mm) } & \multirow[b]{2}{*}{$\mathrm{MSE}^{\mathrm{a}}$} & \multirow[b]{2}{*}{$\mathbf{P}^{\mathbf{b}}$} \\
\hline & $<25$ & $25-150$ & $>150$ & & \\
\hline \multicolumn{6}{|c|}{ (\% of bites). } \\
\hline Pine needle litter & 38 & 42 & 25 & 39 & 0.03 \\
\hline Needles on trees & 0 & 6 & 14 & 19 & 0.04 \\
\hline Other browse & 0 & 16 & 45 & 28 & 0.01 \\
\hline
\end{tabular}

"MSE=root mean square error

${ }^{\mathrm{b}} \mathrm{P}=$ probability of a greater $\mathrm{F}$ value

There was a quadratic relationship between physiological status and total and daylight grazing time. Pregnant cows grazed more during daylight than did open cows at colder temperatures, and this difference increased as temperatures warmed to above freezing (Fig. 1). Cows decreased grazing time as snow depth increased (Table 3). Minimum and maximum time spent grazing was 34 and $552 \mathrm{~min} /$ day, respectively. These grazing times were consistent among cows wearing vibracorders. Partial regressions of total grazing time and grazing during daylight (1200 to 1800 hours) on minimum daily temperature linear and average wind speed linear were significant $(P<0.01)$.

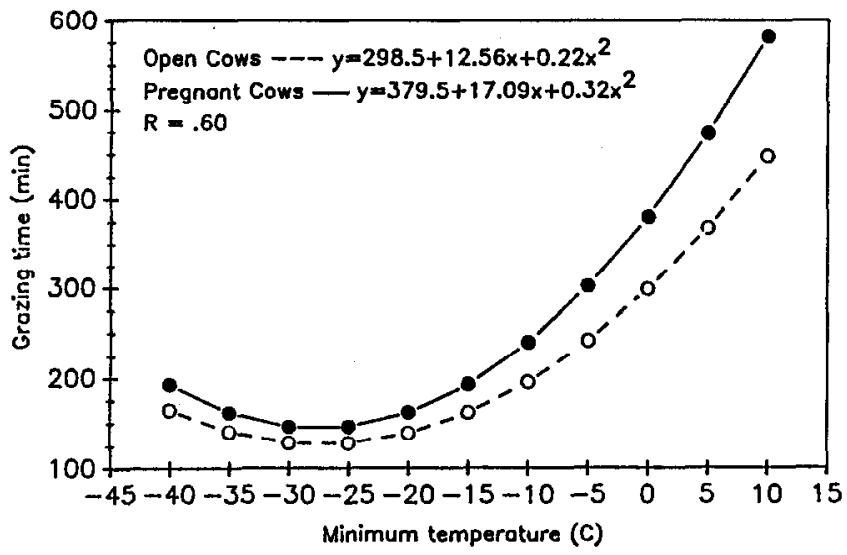

Fig. 1. Dally grazing time (min) from 1200 to 0800 for cows grazing ponderosa pine ranges at different air temperatures in Montana.

Temperatures were extremely variable during the study, with a low minimum daily temperature of $-37^{\circ} \mathrm{C}$ and a high maximum temperature of $13^{\circ} \mathrm{C}$. Average daily wind speed ranged from a low of $<1$ to a high of $24 \mathrm{~km} /$ hour.

Estimated pine tree densities were 140,12, and 332 trees/ ha for the small, medium, and large size classes, respectively. There were $10 \mathrm{~kg} / \mathrm{ha}$ of needles available on trees $<2-\mathrm{m}$ tall, and $17 \mathrm{~kg} / \mathrm{ha}$ of needles available up to a $2-\mathrm{m}$ browsing height on the large trees. In windswept areas with no snow cover, there were an estimated $180-\mathrm{g}$ pine litter $/ \mathrm{m}^{2}$ on the ground in late January.

Table 3. Time spent grazing ( $\mathrm{min} / \mathrm{day}$ ) by pregnant and open cows, and influence of snow depth on grazing time during January to March, 1989 in eastern Montana.

\begin{tabular}{|c|c|c|c|c|c|c|c|}
\hline \multirow[b]{2}{*}{ Grazing period } & \multicolumn{3}{|c|}{ Cow status } & \multicolumn{4}{|c|}{ Snow depth (mm) } \\
\hline & Pregnant & Open & $\mathrm{P}^{\mathrm{b}}$ & $<25$ & $25-150$ & $>150$ & $\mathbf{P}$ \\
\hline & \multicolumn{3}{|c|}{ (min/day) } & & $(\min / \mathrm{day}$ & & \\
\hline Total grazing time & 215 & 164 & 0.02 & 331 & 207 & 155 & $0.60 \mathrm{~ns}$ \\
\hline 1200 to $1759^{a}$ & 162 & 106 & 0.002 & 199 & 148 & 118 & 0.01 \\
\hline 1800 to 0800 & 53 & 58 & $0.98 \mathrm{~ns}$ & 132 & 59 & 37 & 0.03 \\
\hline
\end{tabular}

${ }^{\mathrm{a}}$ Cows were fed daily at about 0830 and did not graze before 1200

${ }^{b} \mathbf{P}=$ probability of greater $F$ value; ns=nonsignificant 
Table 4. Grazing diets (\% of bites or \% in fecal samples) of cattle grazing in pine tree infested pasture during winter, 1990 in Montana².

\begin{tabular}{lcc}
\hline \hline Item & \% of bites & \% in fecal sample \\
\hline Pine needle litter & 0 & - \\
Pine needles from trees $<2 \mathrm{~m}$ & $<1$ & - \\
Pine needles from trees $>2 \mathrm{~m}$ & $<1$ & - \\
Total pine needles & $<1$ & 1 \\
Yucca & 4 & 7 \\
Other browse & $<1$ & 6 \\
Grasses & 95 & 86
\end{tabular}

No treatment differences in any item were noted, therefore only overall means are given.

Cattle were fed alfalfa which was determined in fecal samples, but calculations of grazing diets excluded alfalfa. Fecal analysis can not distinguish various classes of pine needles, therefore only a total in feces is shown.

\section{Trial 2}

Cattle ate few pine needles during Trial 2 (Table 4). Grass made up most of the diets with some yucca. Cattle often did not consume all or even a part of the supplemental alfalfa hay or cubes (data not shown).

Grazing times (total or partial) did not differ between the 2 treatment groups (data not shown). Grazing time from 0600 to 1159 hours was negatively influenced by average wind speed. Grazing time from 1200 to 1759 hours and total grazing time were negatively influenced by snow depth.

Ambient temperature was extremely variable during the study period. During a storm in late December 1989, temperatures fell to $-52^{\circ} \mathrm{C}$. Generally, after this December storm period, the winter was relatively mild, as the maximum daily high temperatures exceeded $0^{\circ} \mathrm{C}$ every day except 8 days from 1 Jan. to 15 Feb. 1990. Average daily wind speed varied from near 0 to about $16-\mathrm{km}$ hour $^{-1}$ during Trial 2.

Dense stands of pine trees covered about $15 \%$ of the pasture. Densities were 600,150, and 200 trees / ha for the small $(<1-m$ tall), medium (1-2-m tall), and large ( $>2 \mathrm{~m}$ ) size classes, respectively. Pine needle litter accumulations were $675 \mathrm{~kg} / \mathrm{ha}$ in the pine tree areas, where essentially all pine litter was concentrated. There were $86 \mathrm{~g}$ of needles/tree within the $2-\mathrm{m}$ browsing zone on trees $>2 \mathrm{~m}$ in height. Needle biomass was $110 \mathrm{~g} /$ tree for trees $<2-\mathrm{m}$ tall. Standing crop of dormant forage in the pasture was $655 \mathrm{~kg} /$ ha in early January 1990.

\section{Discussion}

The abortifacient compound(s) in pine needles is unknown. Recent evidence indicates that abortions are related to reductions in blood flow to the fetus (Christenson et al. 1992a,b), or to abnormal serum hormone levels (Short et al. 1989). During the 1989 study, 1 pregnant cow aborted a dead fetus, and another cow had a weak, but viable full-term calf near the end of the study period. Both cows had been eating substantial quantities of needles. One cow aborted in early January 1990 . Although we did not observe this cow eating pine needles, fecal analysis showed that pine needles made up $1-6 \%$ of the recent diet. Several recent studies have shown that about $600-\mathrm{g}$ pine needles $\mathrm{day}^{-1}$ for 21 days will generally cause abortions in cows in late gestation with no previous exposure to needles (Short et al. 1989). More needles are often required to abort cows when cows have been exposed to small doses of pine needles (Short et al. 1992). Susceptible late-pregnant cows can abort from a single dose of about $200 \mathrm{~g}$ of needles (Pfister, unpublished data).

Pine needles can cause cows to abort within 24 hours or as late as 3 weeks after consumption. Cows in the 1989 study ate 2.4 to $3.1 \mathrm{~kg}$ of pine needles day ${ }^{-1}$, but day-to-day variability was high. James et al. (1989) fed 1.8 to $5.0 \mathrm{~kg}$ of needles to numerous pregnant cows over a 10-year period, and found that the incidence of abortion or premature parturition varied from 0 to $100 \%$ (mean $57 \%$ ) each year, even though needles were collected from similar sites over time. Short et al. (1989) also noted that the abortion response (i.e., proportion of cows aborting) was not directly related to pine needle dose (from 0.7 to $2.7 \mathrm{~kg}$ / day), but that the interval from initiation of feed to abortion was increased by feeding a smaller amount of pine needles.

Winter temperatures and snow depth had a major impact on grazing time of cows during both trials. In grazing trials near Miles City, Adams et al. (1986) found that cattle grazed less at colder temperatures, as did Malechek and Smith (1976) in Utah. Senft and Rittenhouse (1985) modelled cattle response to short-term thermal stress, and indicated that cattle generally reduce feeding activity in response to cold stress. In trial 1, pregnant cows grazed longer at colder and warmer temperatures than did open cows. These cows were in the third trimester of gestation, and we speculate that this was the result of fetal effects on feed requirements and/or ability to tolerate cold. Increased grazing time may have resulted in more pine needle consumption, especially at night as indicated by fecal analysis. Future studies on pine needle abortion should use pregnant cows even though the health risk is high from abortion and retained placentas.

In agreement with Adams et al. (1986), we found that deeper snow depth reduced grazing time, and also altered consumption of pine litter and needles from trees (Trial 1). Deeper snow had the obvious effect of reducing consumption of pine litter. Consumption of needles from trees increased as snow depth increased and as minimum daily temperature declined; cows ate no needles from trees when minimum daily temperatures were near freezing. Cattle may have been switching to a more accessible feed, or needle chemistry may have changed in response to weather. Secondary plant compounds, such as phenolics and terpenes found in needles, deter herbivory (Palo and Robbins 1991). Concentrations of volatile secondary compounds may decrease at the needle surface at lower temperatures. To our knowledge, there are no reports in the literature relating pine needle chemistry to changes in ambient temperature. Concentrations of terpenes in wood oleoresin from pine trees are only slightly affected by season of year (Hanover 1966).

Carbohydrate concentrations may also play a role in consumption (Jones and Roberts 1991). In fall and winter, foliar raffinose and sucrose concentrations increase in conifers (Little 1970, Martin 1987, Hinesley et al. 1992). Further, Hinesley et al. (1992) found that maximal raffinose and sucrose concentrations in Pinus strobus L. and Pinus virginiana L. were related to daily minimal temperatures in the preceding 30 days. It is not known if accumulation and maintenance of high carbohydrate concentrations in conifers is a short-term response to 1 or more cold events, or a cumulative response from long-term exposure to cold temperatures (Hinesley et al. 1992).

Trial 1 had vastly different results compared to Trial 2 . The major observable differences were the amount of standing dead forage (primarily grasses), and the weather. Cattle in Trial 1 entered the study from the drought of 1988 . There was little dormant forage present, compared to abundant forage during Trial 2. The 1988-1989 winter was very cold (average daily minimum and maximum temperatures $-17^{\circ} \mathrm{C}$ and $-5^{\circ} \mathrm{C}$, respectively), whereas the 1989-1990 winter was relatively mild (average daily minimum and maximum temperatures $-12^{\circ} \mathrm{C}$ and $0^{\circ} \mathrm{C}$, respectively), except for the severe cold period in December, 1989.

Our results indicate that weather, especially ambient temperature, is a major factor in cattle consumption of pine needles. Other related factors may be forage availability, snow cover, and grazing time, especially during periods of low winter temperatures. Our 
results suggest that producers should prevent pregnant cattle from having access to pine needles during cold winter periods, and that pine needle consumption, hence abortion risk, is greatly reduced during periods of mild winter weather.

\section{Literature Cited}

Adams, D.C., T.C. Nelson, W.L. Reynolds, and B.W. Knapp. 1986. Winter grazing activity and forage intake of range cows in the northern Great Plains. J. Anim. Sci. 62:1240-1246.

Altmann, J. 1974. Observational study of behavior: sampling methods. Behav. 49:227-265.

Anderson, G.W., M. Hawke, and R.W. Moore. 1985. Pine needle consumption and bark stripping by sheep grazing annual pastures in young stands of widely spaced Pinus radiata and P. pinaster. Agroforestry Systems 3:37-45.

Christenson, L.K., R.E. Short, and S.P. Ford. 1992a. Effects of ingestion of ponderosa pine needles by late-pregnant cows on uterine blood blow and steroid secretion. J. Anim. Sci. 70:531-537.

Christenson, L.K., R.E. Short, J.P. Rosazzo, and S.P. Ford. 1992b. Specific effects of blood plasma from beef cows fed pine needles during late pregnancy on increasing tone of caruncular arteries in vitro. J. Anim. Sci. 70:525-530.

Currie, P.O., D.W. Reichert, J.C. Malechek, and O.C. Wallmo. 1977. Forage selection comparisons for mule deer and cattle under managed ponderosa pine. J. Range Manage. 30:352-356.

Gartner, F.R., F.D. Johnson, and P. Morgan. 1988. Cattle abortion from ponderosa pine reedles: ecological and range management considerations. p. 71-93 In: L.F. James, M.H. Ralphs, and D.B. Nielsen (eds.). The ecology and economic impact of poisonous plants on livestock production. Westview Press, Boulder, Colo.

Hinesley, L.E., D.M. Pharr, L.K. Snelling, and S.R. Funderburk. 1992. Foliar raffinose and sucrose in four conifer species: relationship to seasonal temperatures. J. Amer. Soc. Hort. Sci. 117:852-855.

Hanover, J.W. 1966. Environmental variation in the monoterpenes of Pinus monticola Dougl. Phytochemistry 5:713-717.

James, L.F., J.W. Call, and A.H. Stevenson. 1977. Experimentally induced pine needle abortion in range cattle. Cornell Vet. 67:294-299.

James, L.F., R.E. Short, K.E. Panter, R.J. Molyneux, L.D. Stuart, and R.A. Bellows. 1989. Pine needle abortion in cattle: a review and report of 1973-1984 research. Cornell Vet. 79:39-52.
Jones, E.L., and J.E. Roberts. 1991. A note on the relationship between palatability and water-soluble carbohydrate content in perennial ryegrass. Irish J. Agr. Res. 30:163-167.

Lacey, J.R., L.F. James, and R.E. Short. 1988. Ponderosa pine: economic impact. p. 95-106 In: L.F. James, M.H. Ralphs, and D. B. Nielsen (eds.). The ecology and economic impact of poisonous plants on livestock production. Westview Press, Boulder, Colo.

Little, C.H.A. 1970. Seasonal changes in carbohydrate and moisture content in needles of balsam fir (Abies balsamea). Can. J. Bot. 48:2021-2028.

MacDonald, M.S. 1952. Pine needle abortion in range cattle. J. Range Manage. 5:150-155.

Malechek, J.C. and B.M. Smith. 1976. Behavior of range cows in response to winter weather. J. Range Manage. 29:9-12.

Martin, N.E. 1987. Soluble sugar concentrations in needles and bark of western white pine in response to season and blister rust. USDA Forest Serv. Res. Pap. INT-379, Ogden, Ut.

NRC. 1984. Nutrient requirements of beef cattle. 6th Ed. Nat. Acad. Sci., Washington, D.C.

Palo, R.T., and C.T. Robbins. 1991. Plant defenses against mammalian herbivory. CRC Press, Boca Raton, Fla.

Prister, J.A., D.C. Adams, R.D. Wiedmeier, and R.G. Cates. 1992. Adverse effects of pine needles on aspects of digestive performance in cattle. J. Range Manage. 45:428-533.

SAS. 1987. SAS / STAT for Personal Computers. 6th Ed., SAS Inst., Cary, N.C.

Senft, R.L., and L.R. Rittenhouse. 1985. A model of thermal acclimation in cattle. J. Anim. Sci. 61:297-306.

Short, R.E., R.B. Staigmiller, D.C. Adams, R.A. Bellows, K.E. Panter, J.A. Pfister, and L.F. James. 1989. Effects of feeding pine needles to cattle: abortion response and physiological mechanisms. Proc. The Range Beef Cow Symposium XI, South Dakota State Univ., Rapid City.

Short, R.E., L.F. James, K.E. Panter, R.B. Staigmiller, R.A. Bellows, J. Malcolm, and S.P. Ford. 1992. Effects of feeding ponderosa pine needles during pregnancy: comparative studies with bison, cattle, goats, and sheep. J. Anim. Sci. 70:3498-3504.

Sparks, D., and J.C. Malechek. 1968. Estimating percentage dry weight in diets using a microscope technique. J. Range Manage. 21:264-266.

Uresk, D.W., and W.W. Paintner. 1985. Cattle diets in a ponderosa pine forest in the northern Black Hills. J. Range Manage. 38:440-442. 